Abstracta Iranica Abstracta Iranica

Revue bibliographique pour le domaine irano-aryen

Volume 40-41 | 2019

Comptes rendus des publications de 2017-2018

\title{
Avraham Faust. "Forts or agricultural estates? Persian period settlement in the territories of the former kingdom of Judah"
}

\section{Astrid Nunn}

\author{
(2) OpenEdition \\ Journals \\ Édition électronique \\ URL : http://journals.openedition.org/abstractairanica/49499 \\ DOI : 10.4000/abstractairanica.49499 \\ ISBN : 1961-960X \\ ISSN : 1961-960X \\ Éditeur : \\ CNRS (UMR 7528 Mondes iraniens et indiens), Éditions de l'IFRI
}

\section{Référence électronique}

Astrid Nunn, « Avraham Faust. "Forts or agricultural estates? Persian period settlement in the territories of the former kingdom of Judah" », Abstracta Iranica [En ligne], Volume 40-41 | 2019, document 65, mis en ligne le 30 octobre 2019, consulté le 23 avril 2021. URL : http://

journals.openedition.org/abstractairanica/49499; DOI : https://doi.org/10.4000/abstractairanica. 49499

Ce document a été généré automatiquement le 23 avril 2021.

Tous droits réservés 


\title{
Avraham Faust. "Forts or agricultural estates? Persian period settlement in the territories of the former kingdom of Judah"
}

\author{
Astrid Nunn
}

\section{RÉFÉRENCE}

Avraham Faust. "Forts or agricultural estates? Persian period settlement in the territories of the former kingdom of Judah", PEQ 150/1, 2018, p. 34-59

1 L'on sait que le territoire de l'ancien royaume de Judée était peu peuplé à l'époque achéménide. Les seuls bâtiments connus sont les bâtiments fortifiés interprétés comme forts ou cellules administratives. La disparité entre le manque d'habitations «normales» et le nombre élevé de «forts » (au moins 25) fait douter l'A. de cette interprétation habituelle. En conséquence l'A. reconsidère les «forts" dans leur paysage social, démographique et politique. Il réexamine les objets qui y furent trouvés et arrive à la conclusion que ces installations étaient des domaines agricoles recréés après les destructions liées à la fin du Royaume de Judée. Ils étaient habités par plusieurs familles. 


\section{AUTEURS}

\section{ASTRID NUNN}

Université de Munich 